\title{
HISTOIRE LÉGENDAIRE
}

\author{
I)E \\ LA NOUVELLE-ESPAGNE
}

P.II

M. LE Conte DE CHARENCEY.

Lixtrait du .onrnal de la Sociélé des Américanisles de Paris.

Nouvelle série, Tome VIII, p. 207-269.

Tome IX, p. $41-81$ et p. 339-352.

\section{PARIS}

IIBRAIRIE O. KIIINOKSIEOK

11, Rue de LiLle, 11

1912 